\title{
Expression and signalling characteristics of the corticotrophin-releasing hormone receptors during the implantation phase in the human endometrium
}

\author{
E Karteris, N Papadopoulou, D K Grammatopoulos and E W Hillhouse ${ }^{1}$ \\ Molecular Medicine, Department of Biological Sciences, University of Warwick, Coventry CV4 7AL, UK \\ ${ }^{1}$ The Medical School, University of Leeds, Leeds LS2 9NL, UK \\ (Requests for offprints should be addressed to E Karteris; Email: ekarteris@bio.warwick.ac.uk)
}

\begin{abstract}
Corticotrophin-releasing hormone $(\mathrm{CRH})$ has been identified in several peripheral tissues, including the female reproductive organs. $\mathrm{CRH}$ is expressed in the placenta, myometrium, epithelial endometrium and the endometrial stromal cells at all phases of the menstrual cycle. Similarly, $\mathrm{CRH}$ receptors are present in pregnant and non-pregnant myometrium, placenta and endometrium. Putative roles of $\mathrm{CRH}$ in the endometrium include involvement in implantation, decidualisation and maintenance of pregnancy. In this study we sought to investigate in detail the $\mathrm{CRH}$ receptor repertoire expressed in the human endometrium and their signalling characteristics. Using RT-PCR we were able to demonstrate the expression of $\mathrm{CRH}$ receptor $1 \alpha(\mathrm{CRH}-\mathrm{R} 1 \alpha)$ and $\mathrm{CRH}-\mathrm{R} 2 \alpha$ in the human endometrium. $\mathrm{CRH}-\mathrm{R} 1 \beta$ was present in $40 \%$ of endometrial cDNAs examined. No apparent expression of $\mathrm{CRH}-\mathrm{R} 2 \beta, \mathrm{CRH}-\mathrm{R} 2 \gamma$ or any other $\mathrm{CRH}-\mathrm{R} 1$ splice variants was detected. Chemical cross-linking studies with ${ }^{125}$ I-ovine $\mathrm{CRH}$ revealed that the endometrial $\mathrm{CRH}$ receptor has a molecular weight of $45 \mathrm{kDa}$. Using the non-hydrolysable photoreactive analogue $\left[\alpha_{-}{ }^{32} \mathrm{P}\right] \mathrm{GTP}$-azidoanilide and peptide antisera raised against G-protein $\alpha$-subunits, we then studied coupling of endometrial $\mathrm{CRH}$ receptors to $\mathrm{G}$ proteins. Treatment of endometrial membranes with human $\mathrm{CRH}(100 \mathrm{nM})$ increased the labelling of $\mathrm{Gq}$ and $\mathrm{Gs}$, but not Gi or Go. These results were supported by experiments in epithelial cells of the non-pregnant human endometrium in the secretory phase which showed that $\mathrm{CRH}$ induced increases in both CAMP and inositol trisphosphate levels. These results suggested that $\mathrm{CRH}$ may exert multiple effects in the human endometrium via distinct signalling cascades. These events are possibly mediated via different receptor subtypes.
\end{abstract}

Journal of Molecular Endocrinology (2004) 32, 21-32

\section{Introduction}

Since its discovery, it has become evident that the physiological role of corticotrophin-releasing hormone $(\mathrm{CRH})$ is much wider than initially thought. In the female reproductive system, $\mathrm{CRH}$ and its receptors have been identified in the human placenta, fetal membranes, ovaries (Petraglia et al. 1987, Riley et al. 1991, Mastorakos et al. 1994, Hatzoglou et al. 1996, Asakura et al. 1997, Karteris et al. 1998, 2000), and in the pregnant and non-pregnant myometrium where CRH is thought to play an important role in the mechanism of labour (Hillhouse et al. 1993, Grammatopoulos \& Hillhouse 1999). In addition, maternal decidua synthesises and releases CRH and there is an increase in decidual GRH mRNA expression during gestation (Petraglia et al. 1992).

CRH has also been detected both in vivo and in vitro in normal and neoplastic human endometrial epithelial cells (Makrigiannakis et al. 1995a). In addition, $\mathrm{CRH}$ and its type $1 \mathrm{CRH}$ receptor (CRH-R1) have been detected in human endometrial stromal cells in both the proliferative and secretory phase, the latter involving the decidualisation of stroma (Di Blasio et al. 1997). Recently, the CRH-R1 receptor has also been detected in the human endometrial adenocarcinoma Ishikawa cell line (Graziani et al. 2002). 
In vitro studies of human endometrial cells indicate that $\mathrm{CRH}$ can induce decidualisation of stromal cells (Ferrari et al. 1995) and can also stimulate the production of interleukin (IL)-1 and IL-6 (Zoumakis et al. 2000). It has been hypothesised that endometrial CRH may participate in the initiation of local inflammatory events leading to the formation of egg niddus (Gravanis et al. 2001). Indeed, studies have shown that both epithelial and decidualised stromal cells of the early pregnant rat uterus contain immunoreactive CRH and that the content of $\mathrm{CRH} \mathrm{mRNA}$ and its peptide product is higher in implantation sites of early pregnant rat uterus (Makrigiannakis et al. 1995b).

In rodents, immunoneutralisation of $\mathrm{CRH}$ or blockage of the CRH-R1 receptor site with the antagonist antalarmin decreases the number of live embryos (Athanassakis et al. 1999, Makrigiannakis et al. 2001). The mechanism whereby $\mathrm{CRH}$ promotes blastocyst implantation and early maternal tolerance appears to be via Fas ligand (FasL) expression in human extravillous trophoblasts with an invasive phenotype (Makrigiannakis et al. 2001). This is of increasing importance, since the Fas receptor and its ligand play an important role in the regulation of immune tolerance (Makrigiannakis et al. 2003). The major function of the Fas-FasL interaction is the induction of apoptosis (Nagata 1994), which is one of the key events involved in the implantation of the blastocyst into the receptive endometrium (Selam et al. 2001).

It appears therefore that endometrial $\mathrm{CRH}$ is a potent modulator of blastocyst implantation. The purpose of this study was to investigate in detail the expression, G-protein coupling and signal transduction pathways of $\mathrm{CRH}$ receptors during the implantation phase in the human endometrium.

\section{Materials and methods}

\section{Subjects}

Endometrial biopsy samples $(n=8)$ were obtained from normal fertile women undergoing diagnostic hysteroscopy or laparoscopy for pelvic pain. They were performed on the day corresponding to luteinizing hormone $(\mathrm{LH})+6$ to $\mathrm{LH}+8$ of the cycle. Chronological dating was based on the last menstrual period and histological dating was performed according to the criteria established by Noyers et al. (1950). Women were defined as being normally fertile if they had one or more successful pregnancies, a regular menstrual cycle (25-35 days) and had not received any steroid hormone or an intrauterine contraceptive device for 3 months prior to the collection of the biopsy sample. Their ages ranged from 27 to 39 years. Ethical approval was obtained from the local ethical committee, and informed consent was obtained from each patient before inclusion in this study.

\section{Cell culture}

Primary cell cultures were prepared from endometrial biopsy sample collected in Hank's balanced salt solution containing streptomycin and penicillin $(100 \mu \mathrm{g} / \mathrm{ml})$. The tissue was chopped finely and incubated at $37^{\circ} \mathrm{C}$ in $5 \mathrm{ml}$ Dulbecco's modified Eagle's medium (DMEM) containing $0 \cdot 2 \%$ collagenase (type 1A). After $60 \mathrm{~min}$ of digestion, filtration through a $250 \mu \mathrm{m}$ sieve (Nylon Bolting Cloth; Lockortex, Warrington, Cheshire, UK) was carried out to separate the undigested pieces of tissue and the mucous material from the cells, followed by a second filtration through a $40 \mu \mathrm{m}$ sieve to separate the epithelial cells (predominantly present as glands) from the stromal and red blood cells (single cells) (Fernandez-Shaw et al. 1992). The single cells were collected by centrifugation at $300 \mathrm{~g}$ and the pellet was resuspended in culture medium (DMEM containing 10\% fetal calf serum, $4 \mathrm{mM}$ glutamine and antibiotics). The glands were backwashed from the filter with phosphate-buffered saline (PBS), digested for a further $30 \mathrm{~min}$ as before, collected by centrifugation at $100 \mathrm{~g}$ and resuspended in culture medium. The purified epithelial cells were grown until confluence in two-chamber glass slide flaskettes (Nunc, Inc., Naperville, IL, USA) and fixed in methanol/ acetone $(50: 50)$ for $90 \mathrm{~s}$.

\section{Fluorescent in situ hybridisation (FISH)}

Fixed endometrial epithelial cells were dehydrated by successive washes through ethanol and air-dried. A specific 40-mer synthetic oligonucleotide probe for the CRH-R1 with fluorescein conjugated at their $5^{\prime}$-ends was used in this study (Fluo-CGA CTAGCTGCCCGGCAGGGCTGCGGGGCGA GCAGGTGCG). Hybridisation solution $(100 \mu \mathrm{l})$ containing $1 \mathrm{ng} / \mu \mathrm{l}$ of the probe, was allowed to hybridise at $37^{\circ} \mathrm{C}$ overnight. Slides were then 
Table 1 List of primers used for the amplification of $\mathrm{CRH}$ receptor subtypes in human endometrium

\begin{tabular}{|c|c|c|}
\hline \multirow{3}{*}{$\begin{array}{l}\text { Subtype } \\
\mathrm{CRH}-\mathrm{R} 1 \alpha / \beta\end{array}$} & \multicolumn{2}{|l|}{ Primer } \\
\hline & & \\
\hline & $\begin{array}{l}\text { Sense } \\
\text { Antisense }\end{array}$ & 5'-GGCAGCTAGTGGTTCGGCC-3' \\
\hline $\mathrm{CRH}-\mathrm{R} 1 \mathrm{c}$ & Sense & 5'-ACATCTCAGACAATGGCTAC-3' \\
\hline & Antisense & 5'-TCGCAGGCACCGGATGCTC-3' \\
\hline $\mathrm{CRH}-\mathrm{R} 1 \alpha / \mathrm{d}$ & Sense & 5'-CCGCATCCTCATGACCAAGC-3' \\
\hline & Antisense & 5'-CTCTTCCGGATGGCAGAACG-3' \\
\hline $\mathrm{CRH}-\mathrm{R} 2 \alpha$ & Sense & 5'-AAGGTCCCCACTTGACAG-3' \\
\hline & Antisense & 5'-TAGGGACCCTCGGGGTCCAG-3' \\
\hline $\mathrm{CRH}-\mathrm{R} 2 \beta$ & Sense & 5'-CССTCACCAACCTCTCAGGTCC-3' \\
\hline & Antisense & 5'-CAGGTCATACTTCCTCTGCTTGTC-3' \\
\hline $\mathrm{CRH}-\mathrm{R} 2 \gamma$ & Sense & 5'-CTCAAGCAATCTGCCTACCT-3' \\
\hline & Antisense & 5'-GGCTCACACTGTGAGTAGTT-3' \\
\hline$\beta-$ & $\begin{array}{l}\text { Sense } \\
\text { Antisense }\end{array}$ & $\begin{array}{l}\text { 5'-AAGAGAGGCATCCTCACCCT-3' } \\
\text { 5'-TACATGGCTGGGGTGTTGAA-3' }\end{array}$ \\
\hline
\end{tabular}

placed in preheated $\left(45^{\circ} \mathrm{C}\right) 2 \times \mathrm{SSC}$ buffer, in which they were washed twice, followed by another 10 -min immersion in $0 \cdot 1 \times \mathrm{SSC}\left(45^{\circ} \mathrm{C}\right)$. The tissue sections were rinsed with PBS, and the cell nuclei were visualised by applying the DNA-specific dye 4,6-diamido-2-phenylindole (DAPI) at a final concentration of $1 \mu \mathrm{g} / \mathrm{ml}$.

\section{Immunofluorescence}

Fixed endometrial epithelial cells were washed in PBS and incubated with 3\% bovine serum albumin (BSA) for $1 \mathrm{~h}$ before incubation with the first primary goat polyclonal CRH-R1/2 cross-reactive antibody for $60 \mathrm{~min}$, which was used at $2 \mu \mathrm{g} / \mathrm{ml}$. All dilutions were made in 3\% BSA in PBS. After three washes with PBS, specimens were incubated for 30 min with the second primary mouse monoclonal cytokeratin antibody followed by another set of washes, as before. Incubation with the first secondary anti-goat IgG-fluorescein isothiocyanate (FITG) conjugate was carried out for $2 \mathrm{~h}$ in the dark, followed by three washes with PBS and addition of the second secondary anti-mouse $\mathrm{IgG}-$ tetramethylrhodamine isothiocyanate (TRITG) conjugated antibody for $30 \mathrm{~min}$. Specimens were washed thoroughly and before mounting the coverslips using 90\% glycerol-PBS, the nuclei were stained with DAPI at a final concentration of $1 \mu \mathrm{g} / \mathrm{ml}$. The results were viewed under fluorescent microscope using appropriate filters.

\section{Total RNA extraction and cDNA synthesis}

Total RNA was prepared from individual samples using RNeasyTM Total RNA Kit (QIAGEN, Crawley, East Sussex, UK) according to the manufacturer's guidelines. First-strand cDNA synthesis was performed using RNase reverse transcriptase (GIBCO BRL, Paisley, Strathclyde, UK).

\section{PCR}

All PCR reactions were carried out using Taq DNA polymerase (GIBCO BRL) with $200 \mathrm{ng}$ cDNA for each amplification, as previously described (Karteris et al. 2001b). Briefly, endometrial cDNAs were amplified at $94{ }^{\circ} \mathrm{C}(45 \mathrm{~s})$, $58{ }^{\circ} \mathrm{C}(45 \mathrm{~s}), 72{ }^{\circ} \mathrm{C}(1 \mathrm{~min})$, in a total of 30 cycles with a final extension step at $72{ }^{\circ} \mathrm{C}$ for $10 \mathrm{~min}$. The set of primers for the amplification of the $\mathrm{CRH}$ receptor subtypes and $\beta$-actin are shown in Table 1. Ten microlitres of the reaction mixture were subsequently electrophoresed on a $1 \cdot 6 \%$ agarose gel and visualised by ethidium bromide, using a $1 \mathrm{~kb}$ DNA ladder (GIBCO BRL) to estimate the band sizes. As a negative control for all of the reactions, distilled water was used in place of the cDNA. The resultant PCR products were sequenced in an automated DNA sequencer and the sequence data were analysed using Blast Nucleic Acid Database Searches from the National Centre for Biotechnology Information. 
Table 2 G-protein antisera used in this study. All antisera were raised in rabbits

\begin{tabular}{|c|c|c|c|c|}
\hline & $\begin{array}{l}\text { Size } \\
(k D a)\end{array}$ & $\alpha$-subunit & Sequence & Binding site \\
\hline $\begin{array}{l}\text { Antibody } \\
\text { Gs }\end{array}$ & 47,45 & $\alpha s$ & RMHLRQYELL & C-terminus \\
\hline Go & 40.5 & $\alpha 0$ & GCTLSAEERAALERSK & $\mathrm{N}$-terminus \\
\hline $\mathrm{Gi}$ & 41 & $\alpha \mathrm{i}_{1 / 2}$ & KENLKDCGLF & C-terminus \\
\hline $\mathrm{Gq}$ & 42 & $\alpha_{\mathrm{q} / 11}$ & QLNLKEYNLV & C-terminus \\
\hline
\end{tabular}

\section{Preparation of endometrial membranes}

Tissues were weighed and homogenised in $6 \mathrm{ml}$ Dulbecco's PBS containing $10 \mathrm{mM} \mathrm{MgCl}_{2}, 2 \mathrm{mM}$ EGTA, $0 \cdot 15 \%$ BSA (w/v), 0 $15 \mathrm{mM}$ bacitracin and $1 \mathrm{mM}$ phenylmethylsulfonyl fluoride, $\mathrm{pH} \quad 7 \cdot 2$ (extraction buffer) at $22{ }^{\circ} \mathrm{C}$ for $40 \mathrm{~s}$. The homogenate was centrifuged at 3000 r.p.m. for $30 \mathrm{~min}$ at $4{ }^{\circ} \mathrm{C}$. The resultant pellet was washed, resuspended in extraction buffer, and spun at 19000 r.p.m. for a further $60 \mathrm{~min}$ at $4{ }^{\circ} \mathrm{C}$. The final pellet was resuspended in extraction buffer using homogeniser for $20 \mathrm{~s}$.

\section{Binding studies}

Endometrial membrane suspensions $(100 \mu \mathrm{g})$ were added to polypropylene tubes with $50 \mu \mathrm{l}{ }^{125}$ I-ovine (o) $\mathrm{CRH}$ and ${ }^{125} \mathrm{I}$-urocortin (UCN; 50000 c.p.m.) and $50 \mu \mathrm{l}$ extraction buffer or unlabelled peptides (diluted in buffer). The unrelated peptide arginine vasopressin (AVP) was used as a control. The tubes were incubated at $22{ }^{\circ} \mathrm{C}$ for $2 \mathrm{~h}$ after which the reaction was terminated by the addition of $1 \mathrm{ml}$ ice-cold polyethylene glycol $(20 \% \mathrm{w} / \mathrm{v})$. The tubes were spun at 3000 r.p.m. for $30 \mathrm{~min}$ at $4{ }^{\circ} \mathrm{C}$. The supernatant was discarded and the membranebound radioactivity present in the pellet was measured in a gamma counter.

\section{Chemical cross-linking and SDS-PAGE}

Human endometrial membranes were incubated with ${ }^{125} \mathrm{I}$-oCRH for $2 \mathrm{~h}$ in $300 \mu \mathrm{l}$ buffer $(50 \mathrm{mM}$ Tris-HCl, $2 \mathrm{mM}$ EGTA, $10 \mathrm{mM} \mathrm{MgCl}_{2}$ and $1.5 \mathrm{~g} / \mathrm{l} \mathrm{BSA}, \mathrm{pH} 7 \cdot 2$ ) at $22{ }^{\circ} \mathrm{C}$ to reach equilibrium in the presence or absence of cold CRH $(100 \mathrm{nM})$ to define non-specific binding. Disuccinimidyl suberate $(10 \mu \mathrm{l})$ was added to the preparation to give a final concentration of $1.5 \mathrm{mM}$. The reaction was then allowed to proceed for $10 \mathrm{~min}$ at $22{ }^{\circ} \mathrm{C}$ before termination with $1 \mathrm{ml}$ ice-cold extraction buffer and centrifugation at 12000 r.p.m. for $10 \mathrm{~min}$. The pellets were then washed, solubilised and subjected to SDS-PAGE as previously described (Grammatopoulos et al. 1995). The gel was then dried and exposed to Fuji X-ray film at $-70{ }^{\circ} \mathrm{C}$ for 3 days.

\section{Synthesis of $\left[\alpha^{-32}\right.$ P]GTP-azidoanilide (GTP-AA) and photoaffinity labelling of $\alpha$-subunits}

GTP-AA was synthesised using a method previously described (Grammatopoulos et al. 1999). Human endometrial membranes (150-200 $\mu \mathrm{g})$ were incubated for $3 \mathrm{~min}$ at $30^{\circ} \mathrm{C}$ with $\mathrm{CRH}$ $(100 \mathrm{nM})$ in buffer $\mathrm{G}$ (50 mM HEPES, $30 \mathrm{mM}$ $\mathrm{KCl}, 10 \mathrm{mM} \mathrm{MgCl}_{2}, 1 \mathrm{mM}$ benzamidine and $0 \cdot 1 \mathrm{mM}$ EDTA), followed by the addition of $5 \mu \mathrm{M}$ GDP and $6 \mu \mathrm{Ci}$ GTP-AA. After incubation for $3 \mathrm{~min}$ at $30^{\circ} \mathrm{C}$ in a darkened room, membranes were placed on ice and collected by centrifugation at 13000 r.p.m. for $15 \mathrm{~min}$ at $4{ }^{\circ} \mathrm{C}$. The supernatant was carefully removed, and the membrane pellet was resuspended in $120 \mu \mathrm{l}$ buffer $\mathrm{C}$ containing $1.6 \mathrm{mg} / 5 \mathrm{ml}$ dithiothreitol (DTT). Samples were vortexed and irradiated for 5-10 min at $4{ }^{\circ} \mathrm{C}$ with an ultraviolet light (254 nm) from a distance of $5 \mathrm{~cm}$, to cross-link the GTP-AA to the $\mathrm{G}$ proteins. Immunoprecipitation using $10 \mu \mathrm{l}$ undiluted G-protein antisera (Table 2) was then carried out as previously described (Grammatopoulos et al. 1999).

\section{cAMP studies}

Endometrial cell membrane preparations (50 $\mu \mathrm{g}$ protein) were preincubated with different concentrations of human $(\mathrm{h}) / \mathrm{rat}(\mathrm{r}) \mathrm{CRH}(0 \cdot 1-1000 \mathrm{nM})$, in $50 \mu \mathrm{l}$ extraction buffer for $30 \mathrm{~min}$ at $22^{\circ} \mathrm{C}$, prior 
to the addition of $100 \mu \mathrm{l} 50 \mathrm{mM}$ Tris- $\mathrm{HCl}$ containing $10 \mathrm{mM} \mathrm{MgCl}_{2}, 1 \mathrm{mM}$ EGTA, $1 \mathrm{~g} / 1 \mathrm{BSA}$, $1 \mathrm{mM}$ ATP, ATP regeneration system $(7 \cdot 4 \mathrm{mg} / \mathrm{ml}$ creatine phosphate, $1 \mathrm{mg} / \mathrm{ml}$ creatine phosphokinase), $100 \mu \mathrm{M}$ 3-isobutyl-1-methylxanthine and $0.15 \mathrm{mM}$ bacitracin, $\mathrm{pH} 7 \cdot 4$ at $37^{\circ} \mathrm{C}$. The reaction was terminated after $10 \mathrm{~min}$ by the addition of $1 \mathrm{ml}$ $0 \cdot 1 \mathrm{M}$ imidazole buffer, $\mathrm{pH} 7$, followed by heating of the tubes in boiling water for $5 \mathrm{~min}$. The amount of cAMP in the supernatants was determined by radioimmunoassay.

Standard cAMP concentrations, covering the range $0 \cdot 138-100 \mathrm{pmol} / \mathrm{ml}$, were used for determination of the standard curve of the radioimmunoassay. The interassay coefficient of variation was $8 \%$ cAMP assay buffer (without any membrane preparations) was used as the negative control.

\section{Inositol trisphosphate $\left(\mathrm{IP}_{3}\right)$ assay}

For the $\mathrm{IP}_{3}$ assay, endometrial cell membrane suspensions were incubated with increasing concentrations of $\mathrm{CRH}$, followed by the addition of $200 \mu \mathrm{l} \mathrm{IP} \mathrm{IP}_{3}$ generation buffer containing $25 \mathrm{mM}$ Tris-actetate buffer, $\mathrm{pH} 7 \cdot 2,5 \mathrm{mM} \mathrm{Mg}$ acetate, $1 \mathrm{mM}$ DTT, $0.5 \mathrm{mM}$ ATP, $0.1 \mathrm{mM} \mathrm{CaCl}_{2}$, $0.1 \mathrm{mg} / \mathrm{ml}$ BSA and $10 \mu \mathrm{M}$ GTP. Membranes were incubated for $3 \mathrm{~min}$ at $37^{\circ} \mathrm{C}$, and the reaction was terminated by the addition of $1 \mathrm{M}$ ice-cold trichloroacetic acid, followed by extraction of inositol phosphates and neutralisation. $\mathrm{IP}_{3}$ levels were estimated by radioimmunoassay based on the displacement of ${ }^{3} \mathrm{H}\left[\mathrm{IP}_{3}\right]$ from a specific bovine adrenocortical $\mathrm{IP}_{3}$ binding protein. The interassay coefficient of variation was $11 \cdot 7 \%$.

\section{Statistical analysis}

Data are shown as the mean \pm S.E.M. of each measurement. For the second messenger measurements, a one-way analysis of variance was used, followed by Dunnett's test, in order to compare each treatment dose of CRH with the basal condition. The relative density of the bands was measured by optical density scanning using the software Scion Image-Beta 3b for Windows (Scion Corporation, Frederick, MD, USA). In each case, results were evaluated between groups by using two-tailed Student's $t$-test, with significance determined at the level of $P<0 \cdot 05$.

\section{Results}

\section{Characterisation of cell cultures}

Human endometrial epithelial cell cultures were grown in a monolayer, forming whirl-like structures in the first 2 days and a confluent monolayer by day 5 . The method used for separating glands from stromal cells resulted in a $1-2 \%$ contamination of stromal cells in the epithelial cell cultures, as confirmed by immunocytochemical analysis using anti-vimentin (fibroblast cell marker) and anticytokeratin (epithelial cell marker) (data not shown).

\section{FISH}

FISH was carried out in order to investigate the expression and localisation of GRH-R $1 \mathrm{mRNA}$ in the human endometrial epithelial cells. A specific probe for the GRH-R1 receptor was designed from the N-terminus region of the receptor which recognises the CRH receptor subtypes $1 \alpha$ and $1 \beta$, but not any of the CRH-R2 subtypes. As shown in Fig. 1A, the expression of CRH-R1 receptor mRNA is demonstrated as positive fluorescein staining localised in the cytoplasm of the cells. The cells were also viewed under Hoffman augmented phase contrast, which enabled us to confirm their type by the characteristic epitheloid morphology of endometrial epithelial cells in culture (Fig. 1B). No staining was detectable in endometrial cells probed with sense oligonucleotide probe for the CRH-R1 (Fig. 1C and D). Similar findings were observed when a fluo-probe for the CRH-R2 was utilised (data not shown). In mixed cultures, CRH receptor expression was barely detectable in stromal cells in vitro (data not shown). This might be due to tissue manipulation upon preparation of primary cell cultures, since studies on human myometrial cells have shown loss of CRH receptors as the number of passages of primary cultures increases (Linton et al. 2001, Aggelidou et al. 2002).

\section{Immunofluorescence}

In order to investigate the $\mathrm{CRH}$ receptor protein expression in the endometrial epithelial cell cultures, immunofluorescence was carried out using CRH-R1/2 specific antibody. A plasma membrane rich in positive staining granules was revealed (Fig. 1E). To confirm the type of endometrial cells 

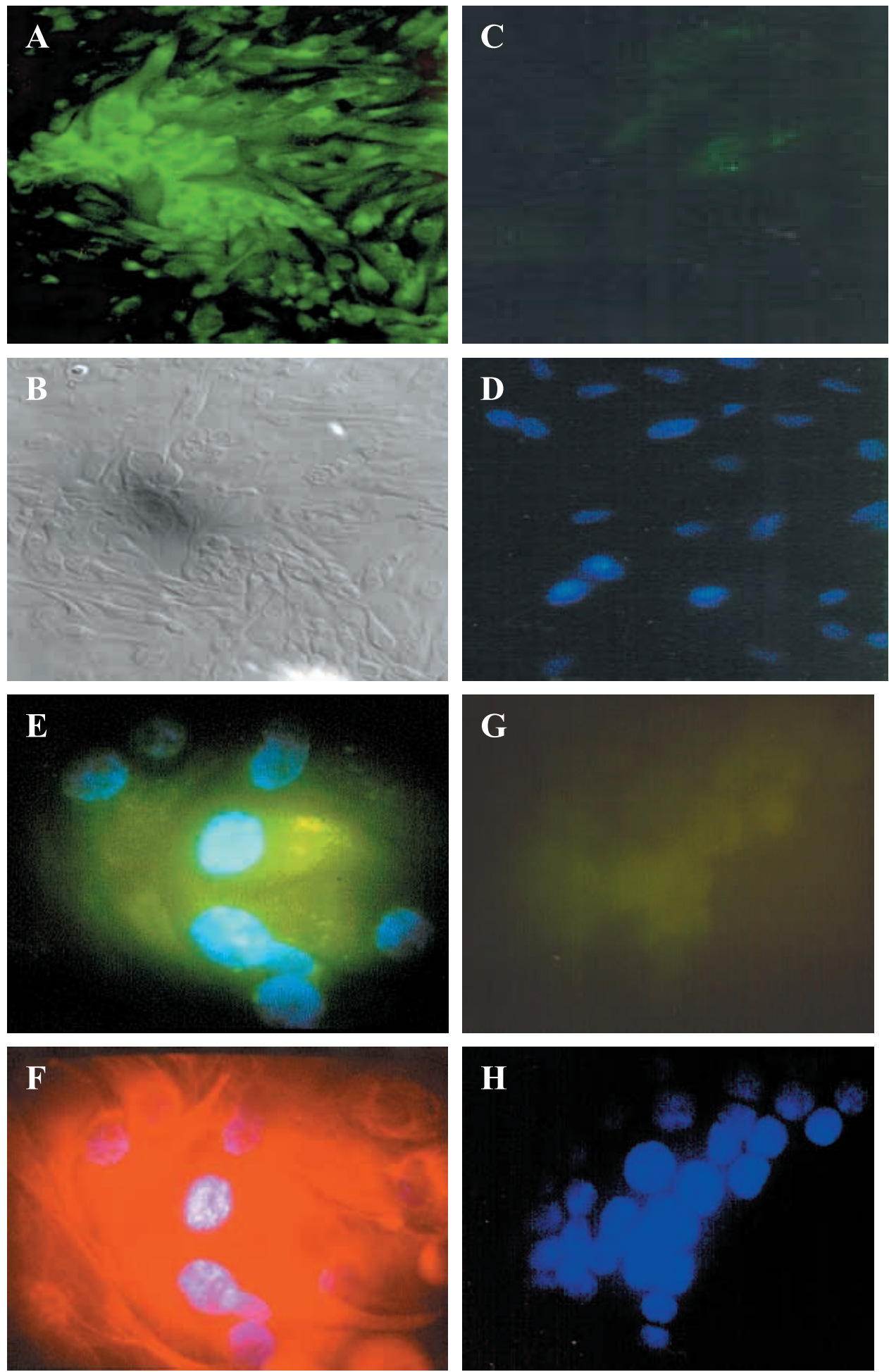
that were immunopositive for the receptor, double staining was performed on the same specimens for CRH-R1/2 and cytokeratin (epithelial cell marker). As shown in Fig. 1F, the endometrial cells were positive for cytokeratin. No staining was detected in the untransfected HEK-293 cells, which were used as negative controls for CRH receptors (Fig. 1G and $\mathrm{H}$ ). These results demonstrated that the human endometrial epithelial cells express the CRH receptor protein.

Furthermore, in agreement with our FISH studies, we were unable to detect any staining for $\mathrm{CRH}$ receptors in stromal cells in vitro (data not shown).

\section{PCR analysis}

Using primers which reverse transcribe either GRH-R $1 \alpha$ or CRH-R1 $\beta$ receptor subtypes we were able to detect CRH-Rl $\alpha$ in endometrial biopsy samples and epithelial cells. However, only $40 \%$ of the cDNAs encoded CRH-R $1 \beta$ mRNA (Fig. 2A). We were unable to detect the CRH-Rlc and CRH-Rld splice variants in this tissue (data not shown). PCR amplification using specific primers for the CRH-R2 receptor subtypes resulted in the detection only of CRH-R2 $\alpha$ in the human endometrium (Fig. 2A). None of the other type-2 receptor subtypes (CRH-R2 $\beta$ and $\mathrm{CRH}-\mathrm{R} 2 \gamma$ ) were detected. Sequence analysis confirmed the identity of all of the PCR products.

\section{Displacement and chemical cross-linking studies}

The presence of functional GRH receptors in endometrial tissue was confirmed by binding displacement studies. h/rCRH and UGN were able to displace ${ }^{125} \mathrm{I}-\mathrm{oCRH}$ and ${ }^{125} \mathrm{I}-\mathrm{UCN}$ respectively from its binding sites in a concentration-dependent manner in endometrial membranes (Fig. 2B). The specificity of the receptor was assessed by coincubating ${ }^{125} \mathrm{I}$-oCRH with the unrelated peptide AVP (at concentrations up to $100 \mathrm{nM}$ ) which was unable to displace ${ }^{125} \mathrm{I}$-oCRH and ${ }^{125} \mathrm{I}$-UGN (data not shown). Using chemical cross-linking, we have also shown that there was a specific CRH-binding site with an apparent molecular mass of $45 \mathrm{kDa}$ (Fig. 2C).

\section{G-protein activation and downstream second messenger generation}

Activation of Gsa and adenylate cyclase system by $\mathrm{CRH}$

In order to identify the $G$ proteins activated by $\mathrm{CRH}$, we use the non-hydrolysable GTP analogue $\left[\alpha-{ }^{32} \mathrm{P}\right] \mathrm{GTP}-\mathrm{AA}$ which binds - upon receptor stimulation - to the GTP-binding site of activated $\mathrm{G} \alpha$ proteins. Immunoprecipitation with specific $\mathrm{G} \alpha$ chain antibodies was used to identify agonistdependent activation of $\mathrm{G}$ proteins (Offermanns et al. 1991).

Our results indicated that treatment of endometrial membranes with $\mathrm{CRH}(100 \mathrm{nM})$ increased the labelling of $\mathrm{Gq}$ and $\mathrm{Gs}$, and but not $\mathrm{Gi}$ or Go which are present in human endometrium (Bernardini et al. 1995). Interestingly, both short forms of $\mathrm{Gs} \alpha$ subunits (47 and $45 \mathrm{kDa}$ ) were activated by $\mathrm{CRH}$ receptors. $\mathrm{CRH}$ increased the incorporation of GTP-AA preferentially to the 47 $(2 \cdot 8 \pm 0 \cdot 2$-fold above basal) rather the $45 \mathrm{kDa}$ isoform $(1 \cdot 6 \pm 0 \cdot 1$-fold above basal). This differential activation of the short Gs isoforms appeared to be significant $(P<0 \cdot 05)$ (Fig. 3A, insert), in all samples tested $(n=4)$.

To test the ability of CRH to activate endometrial epithelial cell adenylate cyclase, we determined the effect of CRH on cAMP production. When membranes from epithelial cells were incubated with CRH (10 pM to $100 \mathrm{nM})$ for $30 \mathrm{~min}$ at $25^{\circ} \mathrm{C}$, there was a significant increase in cAMP production. This increase was found to be

Figure $1 \mathrm{FISH}$ and immunostaining showing the expression of the $\mathrm{CRH}-\mathrm{R} 1$ in epithelial cells of human endometrium. (A) CRH-R1 mRNA expression is shown as fluorescein staining in the cytoplasm of the epithelial endometrial cells; (B) the same field viewed as Hoffman augmented phase contrast. Note the characteristic epitheloid morphology of the cells in culture. (C) No staining was obtained in the endometrial cells hybridised with sense oligonucleotide probe for CRH-R1; (D) the nuclei of the same cells are shown with DAPI staining. (E) CRH-R1 protein detected by immunostaining as fluorescent granules on the cell membrane; $(F)$ double staining of the same cells confirms that endometrial cells which are positive for the receptor are also positive for cytokeratin (epithelial cell marker). (G) Untransfected HEK-293 cells were used as negative control for immunostaining of $\mathrm{CRH}$ receptor protein; $(\mathrm{H})$ the nuclei of the same cells stained with DAPI. 

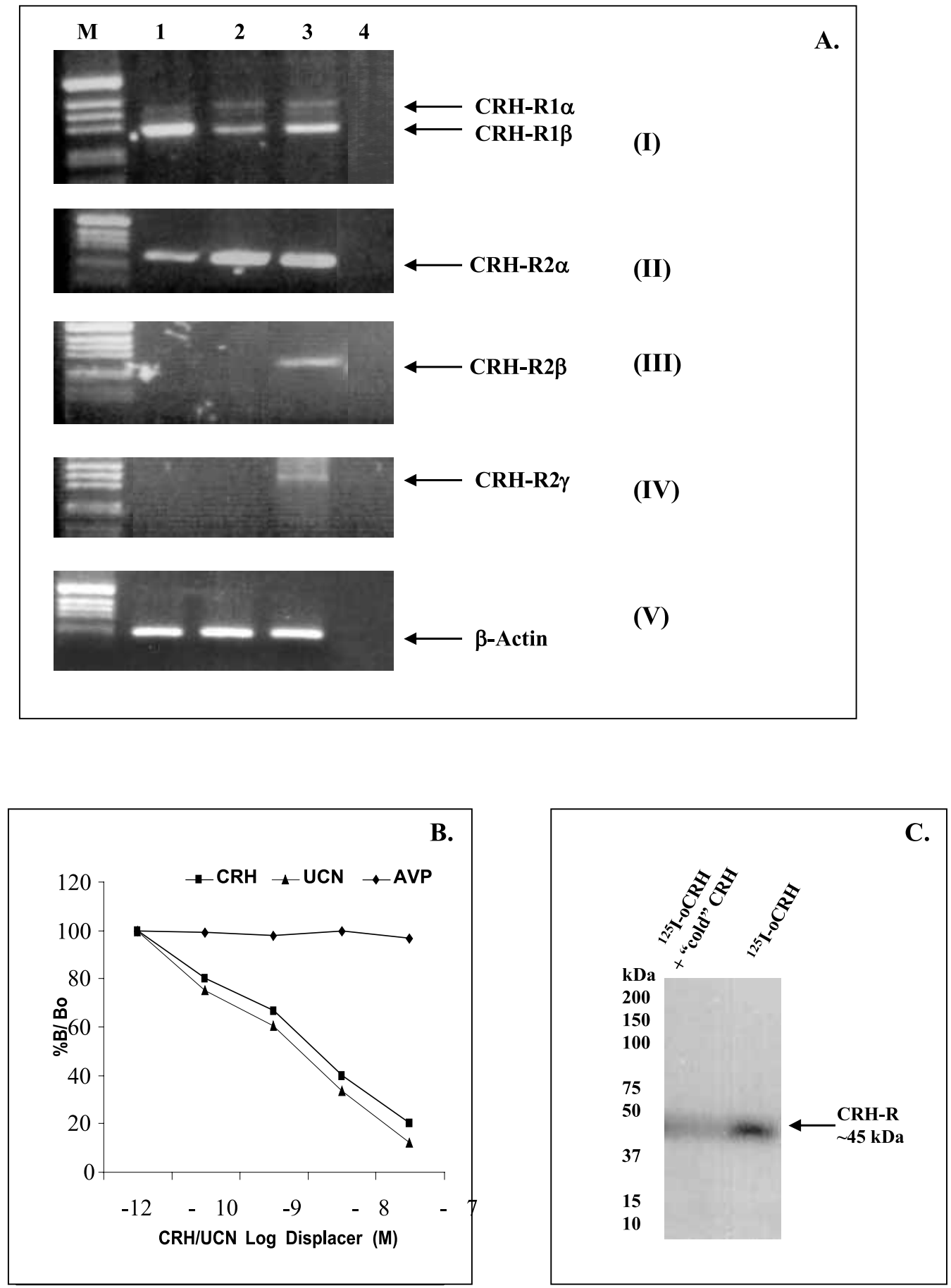

Figure 2 (A) RT-PCR analysis of CRH-R1 $\alpha$ and CRH-R1 $\beta$ (panel I), CRH-R2 $\alpha$ (panel II), $\mathrm{CRH}-\mathrm{R} 2 \alpha$ (panel III), $\mathrm{CRH}-\mathrm{R} 2 \gamma$ (panel IV) and $\beta$-actin (panel V) in human endometrial tissues. Lane $\mathrm{M}$ is the DNA ladder marker, lane 1 is cDNA from cell preparations, lane 2 is cDNA from endometrial tissue, lane 3 is the positive control and lane 4 is the negative control. (B) Displacement curves for binding of ${ }^{125} \mathrm{I}-\mathrm{OCRH}$ and ${ }^{125} \mathrm{I}-\mathrm{UCN}$ to human endometrial membranes. Each point is the mean of four estimations. (C) Autoradiograph of ${ }^{125} \mathrm{I}-\mathrm{oCRH}$ cross-linked to its receptors in human endometrial membranes. The results are representative of three independent determinations. 
A
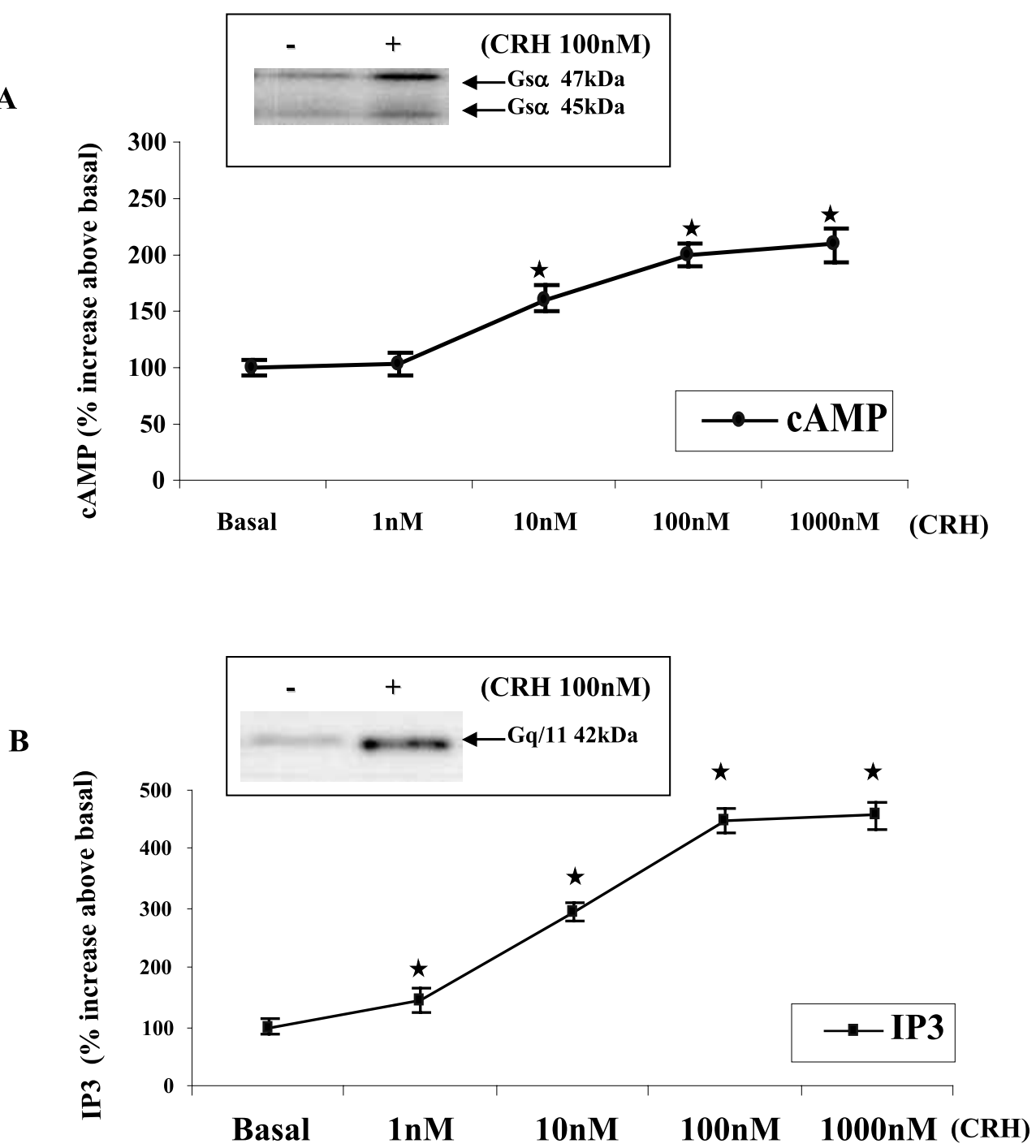

Figure 3 (A) $\mathrm{CRH}$-induced cAMP release from human endometrial membranes in the presence of different concentrations of $\mathrm{h} / \mathrm{rCRH}$. Human endometrial preparations $(50 \mu \mathrm{g}$ protein) were preincubated with different concentrations of $\mathrm{h} / \mathrm{rCRH}(1-1000 \mathrm{nM})$, in $50 \mu \mathrm{l}$ extraction buffer for $30 \mathrm{~min}$ at $22{ }^{\circ} \mathrm{C}$, prior to the addition of $100 \mu \mathrm{l}$ cAMP assay buffer at $37^{\circ} \mathrm{C}$. The reaction was terminated after 10 min and the amount of cAMP in the supernatants was determined by radioimmunoassay. Results are expressed as the mean \pm S.E.M. of four estimations from six independent experiments. ${ }^{*} P<0.05$ compared with basal. (Insert) Identification of Gs $\alpha$-subunits photolabelled with $\left[\alpha^{-32} \mathrm{P}\right]$ GTP-AA from human endometrial membranes in the presence of $\mathrm{CRH}$. Membranes were incubated with $\mathrm{CRH}$ $(100 \mathrm{nM})$, for $5 \mathrm{~min}$ at $30^{\circ} \mathrm{C}$ before the addition of $5 \mu \mathrm{Ci}\left[\alpha^{-32} \mathrm{P}\right] \mathrm{GTP}-\mathrm{AA}$ for $3 \mathrm{~min}$ at $30^{\circ} \mathrm{C}$. Following centrifugation, membranes were placed on ice and exposed to ultraviolet light at a distance of $5 \mathrm{~cm}$ for $5 \mathrm{~min}$.

$\left[\alpha^{32} P\right] G T P-A A-l a b e l l e d ~ G$ proteins were immunoprecipitated and were resolved on SDS-PAGE gels followed by autoradiography. Identical results were obtained from four independent experiments. (B) $\mathrm{CRH}$-induced $\mathrm{IP}_{3}$ accumulation from human endometrial membranes. Membranes $(100 \mu \mathrm{g})$ were incubated with $\mathrm{CRH}(1-1000 \mathrm{nM})$ for $30 \mathrm{~min}$ at room temperature, followed by the addition of $200 \mu \mathrm{II} \mathrm{P}_{3}$ generation buffer and further incubation for 3 min at $37^{\circ} \mathrm{C}$. This was followed by extraction of inositol phosphates and neutralisation. $\mathrm{IP}_{3}$ levels were determined by competitive binding assay. Results are expressed as the mean \pm S.E.M. of four estimations from three independent experiments. ${ }^{*} P<0.05$ compared with basal. (Insert) Identification of $\mathrm{Gq} / 11 \alpha$-subunit photolabelled with $\left[\alpha-{ }^{32}\right.$ P]GTP-AA from human endometrial membranes in the presence of $\mathrm{CRH}(100 \mathrm{nM})$. Identical results were obtained from four independent experiments. 
dose-dependent, showing a threshold of $10 \mathrm{nM}$ CRH, while the maximal response $(210 \pm 15 \%$ of basal) was observed at a concentration of $100 \mathrm{nM}$ (Fig. 3A).

\section{Activation of $G q / 11$ and the phospholipase $C$ (PLC) system by $\mathrm{CRH}$}

Our studies have shown that GRH $(100 \mathrm{nM})$ can also induce coupling to $\mathrm{Gq} / 11(4 \cdot 7 \pm 0 \cdot 2$-fold increase above basal) $(P<0.05)$ (Fig. 3B insert). Activation of $\mathrm{Gq} / 11$ is predicted to stimulate PLC and increase generation of $\mathrm{IP}_{3}$. We found that $\mathrm{CRH}$ treatment of endometrial membranes induced a rapid $\mathrm{IP}_{3}$ turnover, in a dose-dependent manner. This CRH effect has a threshold of $1 \mathrm{nM}$ and a maximum response at $100 \mathrm{nM}(450 \pm 20 \%$ of basal) (Fig. 3B).

\section{Discussion}

In this study we sought to examine the profile of CRH receptor expression and signalling properties in the human endometrium during the implantation phase. In our system we have used cultured epithelial endometrial cells, where CRH receptor was found to be present both at the mRNA and protein level. RT-PCR revealed the presence of at least three different $\mathrm{CRH}$ receptor subtypes: CRH-R $1 \alpha$, CRH-R1 $\beta$ and CRH-R2 $\alpha$. Our data are in agreement with previously published work on endometrial CRH receptors (Di Blasio et al. 1997) and complement recent important findings regarding $\mathrm{CRH}$ and immunotolerance of the fetus (Makrigiannakis et al. 2001, 2003). Using ${ }^{125} \mathrm{I}-$ oCRH, we have confirmed the presence of specific, high-affinity binding sites in human endometrial membranes with an apparent molecular mass of $45 \mathrm{kDa}$.

The functional coupling of $\mathrm{CRH}$ receptors to Gs and $\mathrm{Gq}$ was further confirmed using second messenger studies where it was shown that $\mathrm{CRH}$ was able to induce both cAMP and $\mathrm{IP}_{3}$ accumulation in a dose-dependent manner. Although the concentrations required for significant cAMP and $\mathrm{IP}_{3}$ production were higher than the circulating levels of $\mathrm{CRH}$, it is possible that the human endometrium is exposed to much higher concentrations of $\mathrm{CRH}$ due to the local production of the peptide (Makrigiannakis et al. 1995a).
Interestingly, using RT-PCR and specific primers for different receptor subtypes, we have found that CRH-R1 $\beta$ was expressed only in $40 \%$ of tissues examined. The reasons for this interpatient variation are unknown at present; however, steroid regulation of receptor splicing might be important. Our preliminary evidence suggests that that progesterone treatment affects CRH-R1 splicing at the mRNA level, upregulating CRH$\mathrm{R} 1 \alpha$ and downregulating CRH-R $1 \beta$ in human myometrial cells in vitro (Karteris et al. 2001a). It is attractive therefore to speculate that the downregulation of $\mathrm{CRH}-\mathrm{R} 1 \beta$ might be due to the fact that, in this group of patients, all tissues examined had been exposed to increasing concentrations of progesterone.

Recent studies in our group have also shown that, despite the fact that $\mathrm{CRH}$ and UCN bind with the same affinity to the CRH-R $1 \alpha$, they activate different intracellular signalling cascades (Grammatopoulos et al. 2000). For example, only UCN induces activation of the Erk1/2 pathway, and generates higher $\mathrm{IP}_{3}$ responses when compared with GRH in cells expressing the CRH-R1 $\alpha$ receptor. A recent study has shown that Erk1/2 is activated during rat implantation and may play an important role during the decidualisation process (Thienel et al. 2002). It has also been shown that transient release of calcium from inositol 1,4,5trisphosphate-specific stores regulates mouse preimplantation development (Stachecki \& Armant 1996). It is therefore attractive to speculate that UGN can exert similar effects during human implantation.

We have also demonstrated expression of CRH-R2 $\alpha$ in human endometrium. It has recently been shown that UCN (one the native ligands for CRH-R2) is expressed in human endometrium (Florio et al. 2002). Therefore these data suggest the presence of distinct signalling networks involving UCN and CRH-R2 receptors. With the recent discovery of UCNII and UCNIII acting as native ligands for this receptor, it would be of interest to investigate whether these peptides are expressed in intrauterine tissues, and what signalling cascades they activate.

Our studies have shown that activation of CRH receptors led to stimulation of two signalling cascades: the $\mathrm{Gs} / \mathrm{AC}$ and the $\mathrm{Gq} / \mathrm{IP}_{3}$. This is in accordance with previous studies from our laboratory that have shown that $\mathrm{CRH}$ receptors couple 
to multiple $\mathrm{G}$ proteins in intrauterine tissues (Grammatopoulos et al. 1999b, Karteris et al. 2000). Our experiments have been carried out on material obtained from the secretory phase of the cycle, during which the endometrium prepares itself for implantation or, if implantation fails to take place, for menstruation. Thus, CRH acting via distinct signalling pathways might be implicated in the inflammatory phenomena that take place in the endometrium. For instance, activation of Gs can account for the induction of IL-6 (Zoumakis et al. 2000), FasL expression (Makrigiannakis et al. 2001) or for the generation of antiproliferative effects (Graziani et al. 2002), whereas coupling of CRH receptors to $\mathrm{Gq}$ could lead to induction of IL-1 (Zoumakis et al. 2000). During implantation, there is a major increase in vascular permeability surrounding the implanting embryo, with endometrial capillaries becoming dilated (Gravanis et al. 2001). CRH exerts a potent vasodilatory effect on the uterine artery (Vedernikov et al. 1999). Therefore, the presence of $\mathrm{CRH}$ receptors in epithelial cells and the coupling towards the $\mathrm{Gq} / \mathrm{IP}_{3}$ pathway could account for the regulation of endometrial vasculature, potentially via a nitric oxide-dependent pathway.

In conclusion, $\mathrm{CRH}$ via activation of specific $\mathrm{CRH}$ receptor and coupling to distinct $\mathrm{G}$ protein $\alpha$-subunits may be involved in the sequence of events taking place in the endometrium before and during implantation in co-ordination with other factors deriving from the endometrium or the invading blastocyst. It is tempting to speculate that $\mathrm{CRH}$, acting via different receptor subtypes, is able to exert different actions on the endometrium during the complex phenomena underlying its physiological changes. It is conceivable that abnormalities in this system might cause infertility. Therefore, an understanding of the physiological role of $\mathrm{CRH}$ could lead to novel therapy for some types of infertility or to novel forms of contraception.

\section{Acknowledgements}

Special thanks are due to the Consultants, Gynaecologists and Theatre Staff at the Women's Hospital, University Hospitals of Coventry and Warwickshire NHS Trust, Coventry, West Midlands, for supplying the endometrial biopsy samples and to all patients for participating in this study. E K and N P should be considered first joint co-authors. This work was supported by grants from The Wellcome Trust and the General Charities of the City of Coventry.

\section{References}

Aggelidou E, Hillhouse EW \& Grammatopoulos DK 2002 Up-regulation of nitric oxide synthase and modulation of the guanylate cyclase activity by corticotropin-releasing hormone but not urocortin II or urocortin III in cultured human pregnant myometrial cells. PNAS 99 3300-3305.

Asakura H, Zwain HI \& Yen SS 1997 Expression of genes encoding corticotropin-releasing factor (CRF) type $1 \mathrm{CRF}$ receptor, and CRF-binding protein and localisation of the gene products in the human ovary. Fournal of Clinical Endocrinology and Metabolism $\mathbf{8 2}$ $2720-2724$.

Athanassakis I, Farmakiotis V, Aifantis I, Gravanis A \& Vassiliadis S 1999 Expression of the corticotropin-releasing hormone in the mouse uterus: participation in embryo implantation. Fournal of Endocrinology $163221-227$.

Bernardini L, Moretti-Ro Jas I, Brush M, Ro Jas FJ \& Balmaceda JP 1995 Status of hCG/LH receptor and G proteins in human endometrium during artificial cycles of hormone replacement therapy. Fournal of the Society for Gynecological Investigation 2 630-635.

Di Blasio AM, Giraldi FP, Vigano P, Petraglia F, Vignali M \& Cavagnini F 1997 Expression of CRH and its R1 receptor in human endometrial stromal cells. Fournal of Clinical Endocrinology and Metabolism 82 1594-1597.

Fernandez-Shaw S, Shorter SC, Naish GE, Barlow DH \& Starkey PM 1992 Isolation and purification of human endometrial stromal and glandular cells using immunomagnetic microspheres Human Reproduction 7 156-161.

Ferrari A, Petraglia F \& Gurpide E 1995 Corticotropin-releasing factor decidualizes human endometrial stromal cells in vitro. Interaction with progestin. Fournal of Steroid Biochemistry and Molecular Biology 54 251-255.

Florio P, Arcuri F, Ciarmela P, Runci Y, Romagnoli R, Cintorino M, Di Blasio AM \& Petraglia F 2002 Identification of urocortin mRNA and peptide in the human endometrium. Fournal of Endocrinology 173 R9-R14.

Grammatopoulos DK \& Hillhouse EW 1999 Role of corticotropinreleasing hormone in onset of labour. Lancet 354 1546-1549.

Grammatopoulos D, Thompson S \& Hillhouse EW 1995 The human myometrium expresses multiple isoforms of the corticotropin-releasing hormone receptor. Fournal of Clinical Endocrinology and Metabolism 80 2388-2393.

Grammatopoulos DK, Dai Y, Randeva HS, Levine MA, Karteris E, Easton AJ \& Hillhouse EW 1999 A novel spliced variant of the type 1 corticotropin-releasing hormone receptor with a deletion in the seventh transmembrane domain present in the human pregnant term myometrium and fetal membranes. Molecular Endocrinology 13 2189-2202.

Grammatopoulos DK, Randeva HS, Levine MA, Katsanou ES \& Hillhouse EW 2000 Urocortin, but not corticotropin-releasing hormone $(\mathrm{CRH})$, activates the mitogen-activated protein kinase signal transduction pathway in human pregnant myometrium: an effect mediated via $\mathrm{R} 1$ alpha and R2 beta CRH receptor subtypes and stimulation of Gq-proteins. Molecular Endocrinology 14 2076-2091.

Gravanis A, Makrigiannakis A, Zoumakis E \& Margioris AN 2001 Endometrial and myometrial corticotropin-releasing hormone (CRH): its regulation and possible roles. Peptides 22 785-793. 
Graziani G, Tentori L, Portarena I, Barbarino M, Tringali G, Pozzoli G \& Navarra P 2002 CRH inhibits cell growth of human endometrial adenocarcinoma cells via CRH-receptor 1-mediated activation of cAMP-PKA pathway. Endocrinology 143 807-813.

Hatzoglou A, Margioris AN, Bakogeorgou E, Gravanis A \& Castanas E 1996 Identification, characterisation and localisation of corticotropin-releasing hormone receptors in human placenta. Life Sciences 59 1871-1879.

Hillhouse EW, Grammatopoulos D, Milton NG \& Quartero HW 1993 The identification of a human myometrial CRH receptor which increases in affinity during pregnancy Fournal of Clinical Endocrinology and Metabolism 76 736-741.

Karteris E, Grammatopoulos D, Dai Y, Olah KB, Ghobara TB, Easton A \& Hillhouse EW 1998 Human placenta and fetal membranes express CRH $1 \alpha$ and CRH C variant receptor. Fournal of Clinical Endocrinology and Metabolism 83 1376-1379.

Karteris E, Grammatopoulos D, Randeva HS \& Hillhouse EW 2000 Signal transduction characteristics of the corticotropin-releasing hormone $(\mathrm{CRH})$ receptors in the feto-placental unit. Fournal of Clinical Endocrinology and Metabolism 85 1989-1996.

Karteris E, Zervou S, Old RW, Grammatopoulos DG \& Hillhouse EW 2001a Steroid-mediated expression of CRH-R1, vasopressin $1 \mathrm{~A}$ and oxytocin receptors in the human myometrium.Proceedings of the 83rd Endocrine Society Meeting, Denver, CO, USA P3-623.

Karteris E, Randeva HS, Grammatopoulos DK, Jaffe RB \& Hillhouse EW $2001 b$ Expression and coupling characteristics of the CRH and orexin type 2 receptors in human fetal adrenals. Journal of Clinical Endocrinology and Metabolism 86 4512-4519.

Linton EA, Woodman JR, Asboth G, Glynn BP, Plested CP \& Bernal AL 2001 Corticotrophin releasing hormone: its potential for a role in human myometrium. Experimental Physiology 86 273-281.

Makrigiannakis A, Zoumakis E, Margioris AN, Theodoropoulos P, Stournaras C \& Gravanis A 1995 a The corticotropin-releasing hormone $(\mathrm{CRH})$ in normal and tumoral epithelial cells of human endometrium. Fournal of Clinical Endocrinology and Metabolism $\mathbf{8 0}$ $185-189$.

Makrigiannakis A, Margioris AN, Le Goascogne C, Zoumakis E, Nikas G, Stournaras C, Psychoyos A \& Gravanis A 1995 b Corticotropin-releasing hormone is expressed at the implantation sites of early pregnant rat uterus. Life Sciences 57 1869-1875.

Makrigiannakis A, Zoumakis E, Kalantaridou S, Coutifaris C, Margioris AN, Coukos G, Rice KC, Gravanis A \& Chrousos GP 2001 Corticotropin-releasing hormone promotes blastocyst implantation and early maternal tolerance. Nature Immunology $\mathbf{2}$ $1018-1024$

Makrigiannakis A, Zoumakis E, Kalantaridou S, Mitsiades N, Margioris A, Chrousos GP \& Gravanis A 2003

Corticotropin-releasing hormone $(\mathrm{CRH})$ and immunotolerance of the fetus. Biochemical Pharmacology 65 917-921.
Mastorakos G, Scopa CD, Vryonidou A, Friedman TC, Kattis D, Phenekos C, Merino MJ \& Chrousos GP 1994 Presence of immunoreactive corticotropin-releasing hormone in normal and polycystic human ovaries. Fournal of Clinical Endocrinology and Metabolism 79 1191-1197.

Nagata S 1994 Fas and Fas ligand: a death factor and its receptor. Advances in Immunology 57 129-144.

Noyers RW, Hertig AT \& Rock J 1950 Dating the endometrial biopsy. Fertility and Sterility 1 3-25.

Offermanns S, Schultz G \& Rosenthal W 1991 Identification of receptor-activated $\mathrm{G}$ proteins with photoreactive GTP analog, $\left[\alpha_{-}{ }^{32} \mathrm{P}\right]$ GTP azidoanilide. Methods in Enzymology 195 286-301.

Petraglia F, Sawchenko PE, Rivier J \& Vale W 1987 Evidence for local stimulation of ACTH secretion by corticotropin-releasing factor in human placenta. Nature 328 717-719.

Petraglia F, Tabanelli S, Galassi MC, Garuti GC, Mancini AC, Genazzani AR \& Gurpide E 1992 Human decidua and in vitro decidualised endometrial stromal cells at term contain immunoreactive corticotropin-releasing factor (CRF) and CRF messenger ribonucleic acid. Fournal of Clinical Endocrinology and Metabolism 74 1427-1431.

Riley SC, Walton JC, Herlick JM \& Challis JR 1991 The localisation and distribution of CRH in the human placenta and fetal membranes throughout gestation. Fournal of Clinical Endocrinology and Metabolism 72 1001-1007.

Selam B, Kayisli UA, Mulayim N \& Arici A 2001 Regulation of Fas ligand expression by estradiol and progesterone in human endometrium. Biology of Reproduction 65 979-985.

Stachecki JJ \& Armant DR 1996 Transient release of calcium from inositol 1,4,5-trisphosphate-specific stores regulates mouse preimplantation development. Development 122 2485-2496.

Thienel T, Chwalisz K \& Winterhager E 2002 Expression of MAPkinases (Erk1/2) during decidualization in the rat: regulation by progesterone and nitric oxide. Molecular Human Reproduction $\mathbf{8}$ 465-474.

Vedernikov YP, Saade GR, Chwalisz K \& Garfield RE 1999 Endothelium-dependent and -independent mechanisms of vasorelaxation by corticotropin-releasing factor in pregnant rat uterine artery. Fournal of Pharmacology and Experimental Therapeutics 288 407-413.

Zoumakis E, Margioris AN, Stournaras C, Dermitzaki E, Angelakis E, Makrigiannakis A, Koumantakis E \& Gravanis A 2000 Corticotrophin-releasing hormone $(\mathrm{CRH})$ interacts with inflammatory prostaglandins and interleukins and affects the decidualization of human endometrial stroma. Molecular Human Reproduction 6 344-351.

Received in final form 26 September 2003 Accepted 29 September 2003 